\title{
A Proposal for Comprehensive Biobank Research Laws to Promote Transnational MEDICINE IN INDIANA
}

\author{
Jennifer Girod* \\ Katherine Drabiak**
}

TABLE OF CONTENTS

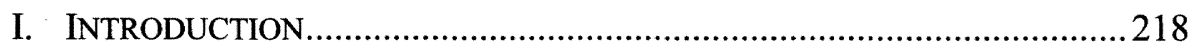

II. THE CURRENT REGULATORY AND LEGAL ENVIRONMENT AND

IMPLICATIONS FOR BIOBANK RESEARCH ...................................220

A. Complex Federal Regulatory Framework............................... 220

B. Public Fears of Genetic Discrimination.....................................223

C. Ambiguity Regarding Tissue Ownership.................................. 225

D. Implications of the Current Regulations on Biobank

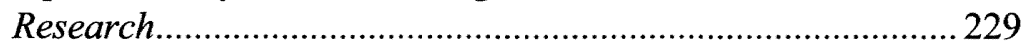

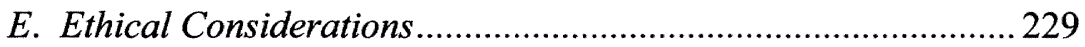

III. STATE APPROACHES TO FEDERAL REGULATORY

INCONSISTENCIES IN GENETIC RESEARCH ....................................231

A. State Legislative Responses: An Overview of Legal

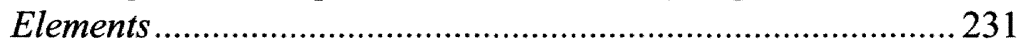

1. Personal Access to DNA Results..........................................232

2. Informed Consent and Exemptions ..................................... 232

3. Retention and Destruction of DNA Samples and Genetic

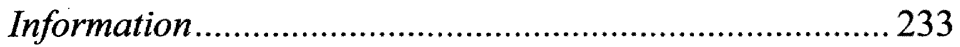

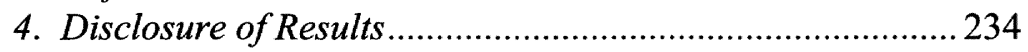

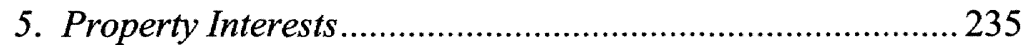

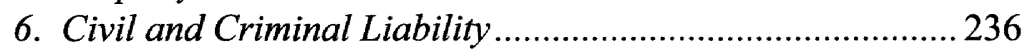

B. State Legislative Strategies to Protect Donors or Promote

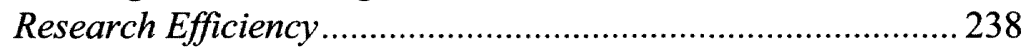

1. State Laws that Increase Protections for Tissue Donors.... 238

2. State Laws that Promote Research Efficiency ..................... 241

* J.D. 2007, Indiana University School of Law, Indianapolis, Indiana; B.A., 1990, M.A., 1992, A.S.N., 1996, Ph.D., 1999, Indiana University. The research for this article was supported by Predictive Health Ethics Research ("PREDICTER"), a multidisciplinary research, policy and public education program of the Indiana University Center for Bioethics funded by a grant from the Richard M. Fairbanks Foundation, Inc. Indianapolis. Thank you to all participants in PREDICTER weekly meetings, who offered comments and suggestions on earlier drafts of this paper. Special thanks to Eric M. Meslin, Ph.D., and Jere O'Dell, M.A., M.L.S., for their help.

** J.D. Candidate, 2008, Indiana University School of Law, Indianapolis, Indiana; B.A., 2005, University of California, Santa Barbara. 


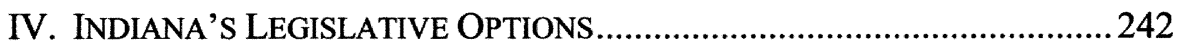

A. Existing Indiana Law Related to Genetic Information................243

1. Repositories or Genetic Information Databases .................. 243

2. Indiana Statutory Definitions of Genetic Testing;

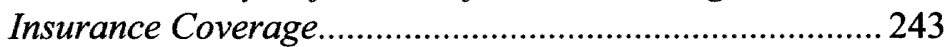

B. Approaches to Addressing Indiana's Lack of Legislation.......... 244

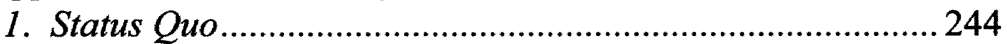

2. A Comprehensive Approach for Indiana.............................. 245

a. Tiered or blanket informed consent for all tissue use... 245

b. Disclosures and re-identification....................................247

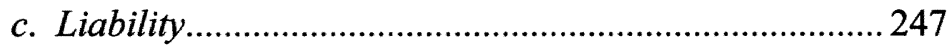

d. Implementation of legislative changes...........................2247

(I) Outreach and education.........................................248

(II) Integration of genomics into personal

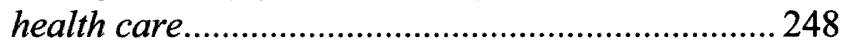

(III) Evaluation and ongoing advisement...................249

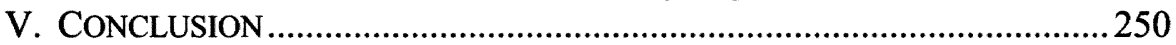

\section{INTRODUCTION}

"Translational medicine" is a term that has come to signify the focused efforts of bench scientists, drug developers, and clinical researchers to develop new medical products and improve health. ${ }^{1}$ Translational medicine is sometimes referred to as "molecular" or "personalized" medicine, and it generally involves the study of "disease and its pathology at the molecular level ... including the levels of such molecules as DNA, RNA, proteins, and metabolites."2 The hope is that this research will lead to personalized health care products, reductions of adverse drug reactions, better methods of identifying individuals at risk for disease, and improvements in preventive care. ${ }^{3}$ It may also eliminate waste in our health care system by decreasing the use of ineffective medications and drugs that cause adverse reactions. ${ }^{4}$

1. BioBank Central, What is Translational Medicine?, http://www.biobankcentral.org/ translational/whatis.php (last visited Mar. 21, 2008).

2. Adam W. Culbertson, Stephen J. Valentine \& Stephen Naylor, Personalized Medicine: Technological Innovation and Patient Empowerment or Exuberant Hyperbole?, DRUG DISCOVERY WORLD 18, 23 (2007).

3. NAT'L CANCER INST., OFFICE OF BIOREPOSITORIES \& BIOSPECIMEN RES., FREQUENTLY ASKED QUESTIONS, http://biospecimens.cancer.gov/resources/faqs/ [hereinafter NATIONAL CANCER INSTITUTE](last visited Feb. 16, 2008).

4. Barbara J. Evans, David A. Flockhart \& Eric M. Meslin, Commentary: Creating Incentives for Genomic Research to Improve Targeting of Therapies, 10 NATURE MEDICINE 1, 2 (2004). 
Biobanks provide vital resources for this industry. Biobanks collect, store, process, and distribute biological specimens and associated patient data to allow researchers to study the connection between molecular information and patients' clinical responses. ${ }^{5}$ Although scientists have long been pursuing research on human biological materials, the recent mapping of the human genome coupled with improved information technology systems has created tremendous potential in biobank research.

At least three legal issues may impede or slow down research from biobanks. ${ }^{6}$ First, the complex federal regulatory structure is ambiguous and internally inconsistent. ${ }^{7}$ Second, there are public fears that genetic information could be used as a basis for discrimination in health care insurance, life insurance, employment and education. ${ }^{8}$ Addressing these concerns requires a careful examination of the legal landscape governing genetic information because several (although not all) research projects using biobanked samples perform genetic analyses. Third, the law is unclear regarding ownership of human tissues, which has led to bitter disputes and lawsuits and creates uncertainty among potential purchasers of the tissue who wish to create commercial products from them. ${ }^{9}$

The Indiana General Assembly may soon face pressure from both privacy advocates who wish to enhance patient protections, as well as those institutions or commercial sponsors who would like to streamline the process for collecting and using human tissues. Examining the intersecting concerns regarding genetic information and legal barriers to research and development will enable Indiana to address these issues proactively and hasten the realization of translational research's promises of health care delivery. Identifying areas of legal confusion and adopting a comprehensive legal framework for our state is crucial to assisting the development of research discoveries originating from banked specimens.

Part II of this Article discusses the current regulatory and legal environment of genetic research, the implications for biobank-related research, and the ethical values that should guide state legislative responses. Part III outlines

5. NATIONAL CANCER INSTITUTE, supra note 3.

6. This is not meant to suggest that legal issues are the only ones affecting the pace of research. There may be many other factors, including funding, but those are beyond the scope of this Article.

7. Barbara J. Evans \& Eric M. Meslin, Encouraging Translational Research Through Harmonization of FDA and Common Rule Informed Consent Requirements for Research with Banked Specimens, 27 J. LEGAL MED. 119, 119 (2006).

8. Norman-Bloodsaw v. Lawrence Berkeley Lab. 135 F.3d 1260 (9th Cir. 1998); Equal Emp. Opportunity Comm'n v. Burlington N. \& Santa Fe Ry. Co., 2002 WL 32155386 (E.D. Wis. 2002); Louise McIntosh Slaughter, Genetic Testing and Discrimination: How Private Is Your Information? 17 STAN. L. \& POL'Y REV. 67, 71 (2006).

9. Gillian Haddow et al., Tackling Community Concerns About Commercialization and Genetic Research: A Modest Interdisciplinary Approach, 64 Soc. ScI. \& MED. 272, 272 (2007); see also Radhika Rao, Genes and Spleens: Property, Contract, or Privacy Rights in the Human Body?, 35 J. L. MED. \& ETHICS 371, 372 (2007). 
state legislative efforts to address the shortcomings of federal regulations. Part IV describes Indiana's current statutory law on genetic research and offers a comprehensive solution which the Indiana legislature may choose to adopt to address current legal uncertainties in a way that appropriately balances ethical values. This final section also includes a description of statutory provisions, which include a plan for the Indiana State Department of Health to implement these legislative changes in a way that will encourage consistency among institutions and promote public support of translational research.

\section{THE CURRENT REGULATORY AND LEGAL ENVIRONMENT AND IMPLICATIONS FOR BIOBANK RESEARCH}

Part I of this Article describes the federal regulatory framework governing research with banked specimens and highlights current inconsistencies between the "Common Rule," the "Privacy Rule" of the Health Insurance Portability and Accountability Act of 1996 ("HIPAA"), and Food and Drug Administration ("FDA") regulations. This section of the Article discusses barriers to donation, including public fears of discrimination in employment and insurance benefits based on an individual's genetic information, and case law disputes related to ownership or disposition of donated specimens. This section also reviews ethical considerations that states should balance when considering the legal framework for genetic research from biobanks, including promoting research advancements, respecting individual autonomy, and ensuring individuals' privacy and confidentiality.

\section{A. Complex Federal Regulatory Framework}

Ambiguity and inconsistency plague the three primary federal regulations that govern biobanks. The Common Rule was created under the Department of Health and Human Services ("DHHS") to protect the rights and welfare of human subjects and applies to all non-exempt research conducted by or supported by seventeen federal agencies. ${ }^{10}$ Tissue donors are considered human research subjects only when their tissue is collected for an identified research project and the donor's private information is readily identifiable by the investigator. ${ }^{11}$ This excludes any specimens that were collected in the past (for clinical or other research uses), and potentially excludes specimens collected for future uses (in biobanks) that are not readily identifiable to the researcher. However, the Common Rule does apply to identifiable coded samples collected, stored, and used in a biobank. Informed consent is required for those research projects un-

10. See 45 C.F.R. $\S \S 46.101$ and 46.102 (2005) (regulations that define the Department of Health and Human Services' research policies for protecting human research subjects).

11. 45 C.F.R. $\S 46.102$ (2008). 
less an Institutional Review Board ("IRB") determines that it meets the following four conditions:

(1) The research involves no more than minimal risk to the subjects; (2) The waiver or alteration will not adversely affect the rights and welfare of the subjects; (3) The research could not practicably be carried out without the waiver or alteration; and (4) Whenever appropriate, the subjects will be provided with additional pertinent information after participation. ${ }^{12}$

The FDA does not follow the Common Rule, but has its own set of regulations intended to protect the rights, safety, and welfare of subjects in FDAregulated clinical investigations. ${ }^{13}$ Unlike the Common Rule, its provisions do not distinguish between identifiable and non-identifiable tissues. The FDA has similar rules regarding informed consent for human subjects, but it does not allow IRBs to waive those requirements under any circumstances. ${ }^{14}$

Finally, the HIPAA Privacy Rule covers research uses of "protected health information" ("PHI"), which does not apply to the specimens themselves, but rather to the PHI associated with specimens. ${ }^{15}$ The Rule's purpose is to protect individuals' privacy, confidentiality, and security interests in their PHI. In general, HIPAA's Privacy Rule prevents a covered entity from disclosing an individual's PHI for research purposes without express authorization. Federal guidance asserts that the "creation of a research database or repository, and the use or disclosure of PHI from a database or repository for research, may each be considered a research activity under the Privacy Rule." ${ }^{\prime 16}$ Both of those activities are thus subject to the Privacy Rule. HIPAA governs coded or identifiable data such as names, social security numbers and medical record numbers, and allows an individual to have the option to sign an authorization allowing the research institution to have access to this information. HIPAA's Privacy Rule does not apply to data if it has been de-identified through statisticallyapproved methods or if most personal identifying information has been removed. However, some categories of information which link an individual to a particular population group (race, ethnicity, and socioeconomic status) may remain intact and still be considered legally de-identified. The Privacy Rule also permits the use of limited data sets, which must be stripped of direct identifiers,

12. 45 C.F.R. $\S 46.116(d)(2007)$.

13. 21 C.F.R. $\S \S 50,56,812(2008)$.

14. Evans \& Meslin, supra note 7, at 129.

15. 45 C.F.R. $\S \S 160.103 \& 164$ (2008).

16. DEP'T OF HEAlth \& HuMAN SERVICES, RESEARCH REPOSITORIES, DATABASES, AND THE HIPAA PRIVACY RULE (2004), available at http://privacyruleandresearch.nih.gov/pdf/rese arch_repositories_final.pdf. 
but may include indirect identifiers such as birth date and treatment date. Limited data sets must be accompanied by a data use agreement. ${ }^{17}$

These regulations and associated guidance fail to provide researchers clear directives, particularly with regard to informed consent requirements. Three examples typify the ensuing confusion. First, both the Common Rule and HIPAA are unclear about whether subjects may give informed consent for future, unspecified uses of their tissues, though the practice is widespread and not expressly prohibited. ${ }^{18}$ Second, the Common Rule and FDA regulations are inconsistent regarding the ability of IRBs to waive the requirement for written informed consent. ${ }^{19}$ Third, there is conflicting guidance on whether the informed consent statement may be used, in part, as a vehicle by which subjects waive future rights to profit from commercial products created from their tissues. ${ }^{20}$

Federal regulations provide ambiguous and inconsistent guidance, and they also leave a sector of the research community unregulated. States relying solely on federal regulations have no control over research that may be performed by private institutions or corporations. Private research institutions or repositories that do not receive federal funding are not bound by federal regulations that govern human subject research and the confidentiality of personal health information. In addition, federally regulated researchers, hospitals, and providers sometimes sell or donate collected data and tissues to commercial research sponsors who make additional use of the data and materials that may not be consistent with the informed consent form originally signed by the subject. As one attorney with experience negotiating these agreements notes:

17. Limited data sets are data sets stripped of certain direct identifiers that are specified in the Privacy Rule. These data sets may be used or disclosed only for public health, research, or health care operations purposes. They are not considered de-identified information under the Privacy Rule. Before disclosing a limited data set to a researcher, a covered entity must enter into a data use agreement with the researcher, identifying the researcher as the recipient of the limited data set, establishing how the data may be used and disclosed by the recipient, and providing assurances that the data will be protected, among other requirements. See 45 C.F.R. $\S$ 164.514 (2006).

18. Mark Barnes \& Kate Gallin Heffernan, The 'Future Uses' Dilemma: Secondary Uses of Data and Materials by Researchers and Commercial Research Sponsors, 3 MED. RES. LAW \& POL'Y 440, 442 (2004).

19. The Common Rule states that an IRB can waive the requirement to obtain informed consent for research when four conditions are met. 45 C.F.R. $\S 46.116(d)$. By contrast, the FDA does not allow IRBs to waive the informed consent requirement. 21 C.F.R. $\S 50.20$ (1999).

20. The Office of Protection of Research Risks ("OPRR"), now the Office for Human Research Protections ("OHRP"), has stated guidance that its "regulations are not intended to prohibit the informed subject from making a legitimate donation." Letter from F. William Dommel, Jr., J.D., Dir., Div. of Compliance, OPRR, to Merel P. Glaubiger, Univ. Counsel, Univ. of Cal. at Berkeley (Mar. 21, 1989) (quoted in Barnes \& Heffernan, supra note 18, at 445). The FDA states that donors cannot waive rights as condition for study participation, and that the word "donation" should not be used because it connotes abandonment. FoOD \& DRUG ADMIN., INFORMATION SHEETS: GUIDANCE FOR INSTITUTIONAL REVIEW BOARDS AND CLINICAL INVESTIGATORS, 1998 UPDATE (1998). 
[O]ver the past years, massive quantities of subjects' data and biologic materials have been handed over to commercial sponsors that are largely unrestrained by contract or by regulation from doing with these data and tissue as they will - and they may even be free, from a legal perspective, to use subjects' data for marketing surveys and direct patient marketing. ${ }^{21}$

These research sponsors are subject to FDA regulations only if they are using the research to support an FDA application. Otherwise, this use of data and tissues takes place without oversight from the IRB of the institution where the tissue was collected, and without being regulated by the Common Rule, FDA, or HIPAA. Commercial sponsors may voluntarily enter into clinical trial agreements ("CTA") with institutions from which they acquire tissues, but those CTAs rarely contain provisions relating to the privacy of personal health information. ${ }^{22}$

\section{B. Public Fears of Genetic Discrimination}

Vague and inconsistent federal regulation of biobank research likely has a chilling effect on researchers and investors, but it is the fear of genetic discrimination that appears to have captured the public's imagination. Statistics show that the public's willingness to allow employers or insurance providers access to their genetic testing results has decreased over the past few years. According to studies conducted by Johns Hopkins' Genetics and Public Policy Center, in 2002 eighty-five percent of individuals surveyed did not want employers to have access to their genetic information. ${ }^{23}$ That number increased to ninety-two percent by 2004. Individuals also expressed similar opinions about health insurers' access to genetic information. In 2002, sixty-eight percent of surveyed individuals said their genetic information should be kept private from health insurers, and by 2004 , this number rose to eighty percent. ${ }^{24}$ Studies show that public apprehension derives from the possibility of discrimination or "misuse of genetic testing results by insurance companies or employers." 25

Currently, no federal prohibition exists to prevent discrimination based on genetic characteristics. ${ }^{26}$ Some states have addressed the absence of federal

21. Barnes \& Heffernan, supra note 18 , at 442.

22. Id.

23. Slaughter, supra note 8, at 71.

24. See id.; see also Mary R. Anderlik \& Mark A. Rothstein, Privacy and Confidentiality of Genetic Information: What Rules for the New Science?, 2 ANN. REV. GENOMICS HuM. GENETICS 401, 406-07 (2001) (discussing focus group results of public support and willingness to contribute to genetic research).

25. Yeal Bregman-Eschet, Who Controls Our Genetic Privacy?, 23 Santa Clara COMPUTER \& HiGH TECH. L.J. 1, 13 (2006).

26. The Genetic Information and Nondiscriminatory Act of 2008 (GINA), H.R. 493, 
regulation by enacting statutory prohibitions related to genetic discrimination in employment or insurance contexts. "Most states prohibit employers from requiring genetic testing as a pre-employment condition or ban its use in health insurance altogether." 27 Despite these statutory provisions, some statutes do not apply to discrimination in all insurance related contexts, protect individuals only as long as they are asymptomatic, or do not apply to insurance acquired through an employer. ${ }^{28}$ State law also differs when defining what constitutes discrimination, or whether the law provides any legal remedy to the aggrieved individual. $^{29}$

Some scholars, including Henry Greely, argue that widespread public fear is unfounded because few cases of genetic discrimination have been documented. ${ }^{30}$ However, people's concerns do not seem irrational in light of the nature of documented cases. In Norman-Bloodsaw v. Lawrence Berkeley Laboratory, administrative and clerical workers filed suit arising from their employers' mandatory "employment entrance exams." 31 The employer conditioned employment on these "health evaluations," ordered the employees to contribute blood and urine samples, and then used those samples to conduct genetic testing to identify whether the potential employee had a sickle cell trait and other, non-genetic health conditions. ${ }^{32}$

Although Norman-Bloodsaw occurred prior to substantial state legislation intended to protect against genetic discrimination, a more recent case suggests

110th Congress, passed the House and the Senate on April 24th, 2008, and is awaiting Presidential approval. It is expected that President Bush will sign the bill into law. GINA, first introduced in 1995 as the Genetic Privacy and Nondiscrimination Act, prevents insurers from denying "insurance coverage or adjust [ing] premium rates paid by the individual or the group to which the individual belongs." And, in the context of employment, GINA bars both public and private sector employers "from making employment related decisions based on genetic information of applicants and employees." It would make it unlawful to refuse to hire or discharge employees based on genetic information. Included in the GINA definition of genetic information is an applicant's/employee's family history. See Slaughter, supra note 8, at 74.

27. Jonathan Weems, A Proposal for a Federal Genetic Privacy Act, 24 J. LEGAL MED. 109, 117 (2003).

28. See Mark Rothstein, Expanding the Ethical Analysis of Biobanks, 33 J.L. MED. \& ETHICS 89, 90 (2005) (Rothstein notes that some statutes would not prohibit the employer from "obtaining the results of genetic tests recorded in individual medical records."). But see Henry Greely, Genotype Discrimination: The Complex Case for Some Legislative Protection, $149 \mathrm{U}$. PA. L. REV. 1483, 1488-99 (2001) (Greely distinguishes that medical underwriting may only apply in circumstances where an individual purchases individually underwritten health care coverage. According to Greely, the majority of Americans (including Medicare or Medicaid beneficiaries) are covered without regard to their future risk).

29. Some states prohibit discrimination based on genetic results only in some contexts, but allow genetic results to be used as a factor to determine actuarial risk or when allocating life insurance. Cf. N.Y. CIV RTS. LAW § 79-l (McKinney 1997) and N.M. CODE ANN. § 24-21-4 (2005); see also Weems, supra note 27, at 117-18.

30 . Greely, supra note 28 , at 1490 . Greely also maintains that the rarity of genetic markers for diseases, the weakness of genetic markers in making predictions, the speed of employee turnover, and health care costs would prevent any recognizable financial incentives for employer insurance providers to discriminate on the basis of genetic testing results. 1998).

31. See Norman-Bloodsaw v. Lawrence Berkeley Lab., 135 F.3d 1260, 1271 (9th Cir.

32. Id. 
genetic discrimination still may pose a concern. In 2001, the Equal Employment Opportunity Commission ("EEOC") filed a claim against the Burlington Northern and Santa Fe Railway Company ("BNSF") alleging Americans with Disabilities Act ("ADA") violations. The EEOC claimed that BNSF was requesting employees who developed carpal tunnel syndrome, a work-related injury, to undergo a medical evaluation which included a diagnostic blood test for a genetic marker related to carpal tunnel syndrome. The unreported settlement agreement enjoined BNSF from requiring or requesting current or former employees to submit to genetic testing and ordered BNSF to return the genetic samples to the employees. ${ }^{33}$ However, the agreement did not prevent BNSF from requiring a genetic test for future employees or as a condition of employment.

Discrimination based on genetic results may also be underestimated because it is difficult to document and prove. Individual members of the public and employers may interpret results of potentially stigmatizing group-based genetic research and implicate other members of the group through unconscious or unspoken bias. ${ }^{34}$ Unlike other instances of discrimination, individuals may not even be aware that their genetic information has been collected or is being used in a discriminatory manner.

\section{Ambiguity Regarding Tissue Ownership}

Issues of control arise when individuals' biological specimens and samples are used by researchers, and the use does not conform to the individual's expectations or to the actual informed consent agreement. ${ }^{35}$ Members of the public may also believe that they "own" their genetic material; thus, an institution's or court's assertion to the contrary is seen as an assault on privacy or dignity. ${ }^{36}$ Many of the current informed consent statements used during the

33. Equal Emp. Opportunity Comm'n v. Burlington N. \& Santa Fe Ry. Co., No. 02-C0456, 2002 WL 32155386 (E.D. Wis. May 8, 2002); see also Press Release, EEOC Settles ADA Suit Against BNSF for Genetic Bias (April 18, 2001), available at http://www.eeoc .gov/press/4-18-01.html.

34. Rothstein, supra note 28, at 91 ; see also Alice Hsieh, $A$ Nation's Genes for a Cure to Cancer: Evolving Ethical, Social, and Legal Issues Regarding Population Genetic Databases, 37 Colum. J.L. \& Soc. PROBS. 359, 410 (2004).

35. See Jasper Bovenberg, The New Case for an Inalienable Property Right in Human Biological Material: Empowerment of Sample Donors or a Recipe for a Tragic Anti-Commons? 1 SCRIPT-ED 545 (2004), available at $\mathrm{http} / / / \mathrm{www}$. law.ed.ac.uk./ahrc/script-ed/issue4/bovenberg .asp; see also Haddow et al., supra note 9.

36. See Marina Whelan, What, If Any, Are the Obligations of the U.S. Patent Office?: A Closer Look at the Biological Sampling of Indigenous Populations, 14 DUKE L. \& TECH. REV. (2006) available at http://www.law.duke.edu/journals/dltr/articles/2006DLTR0014.html. Whelan notes that the UN has supported the view that individuals should have property rights in their biological material and should not be forced to assimilate to the framework adopted by some researchers. Unlike the UN's view, Henry Greely believes that once genetic material is separated from the body, the individual no longer shares a relationship with the genetic material. Id., citing Henry T. Greely, Symposium: International Health Law, The Control of Genetic 
procurement of genetic specimens explicitly state that the donor has no express interest or right to their genetic sample following donation. ${ }^{37}$

Some tissue donors wish to place limitations or impose a governance structure on the institution to limit the scope, type, or location of the research as a condition of donation. Empirical research studying public attitudes regarding hypothetical research scenarios as well as actual donors' attitudes indicates that certain members of the public value the following factors, by being able to: (1) authorize the use of their genetic sample for only a particular type of research; (2) prevent the genetic sample from being used for other types of research not authorized; (3) limit where the research is being conducted (i.e. authorizing research only at this specific institution, research only by public or non-profit corporations, research only in the United States); or (4) limit the time period for usage. $^{38}$

As legal scholar Radhika Rao has noted, courts addressing ownership disputes have generally refused to recognize an individual's property right in excised specimens, but do recognize an institution's right to maintain, use, or develop products resulting from the specimens. ${ }^{39}$ There are several notable examples of these conflicts. Moore $v$. Regents of the University of California ${ }^{40}$ is the classic case, in which John Moore, a patient who underwent treatment for leukemia at the UCLA Medical Center, brought an action against his physician and the UCLA Board of Regents when he discovered that they created a patented cell line from his tissues without his knowledge or consent. The Moore court set what became a very influential judicial precedent when it held that Moore's excised tissues were not his property, but belonged to the researchers who used them to develop cell lines. ${ }^{41}$

Research: Involving the "Groups Between," 33 Hous. L. REV. 1397, 1414-15 (1997).

37. Gary Marchant, Property Rights and Benefit-Sharing for DNA Donors? 45 JURIMETRICS J. 153, 155 (2005).

38. Paul Helft et al., Cancer Patients' Attitudes Toward Future Research Uses of Stored Human Biological Materials, 2 J. EMPIRICAL RES. HuM. RES. ETHICS 15, 18-19 (2007). Helft et al. studied the attitudes of cancer patients who had contributed tissue samples to a tissue bank. Helft found that respondents were more likely to disagree with using their stored tissues for future studies on diseases other than their type of cancer. Respondents were also less likely to be willing to allow their tissue samples to be used by researchers not affiliated with local researchers. Haddow et al.'s interviewed focus groups to obtain public opinion s relating to Generation Scotland, an arm of U.K. Biobank. Although this study was conducted in Scotland, several of the responses are relevant and echo concerns arising in U.S. judicial disputes. Several respondents stated that they would have reservations about donating specimens for mental health research, and viewed this category of research as potentially stigmatizing. Respondents also noted that they felt apprehension relating to research uses not specifically authorized, stating that all research uses should be disclosed and the specimens should only be used for the purpose to which the donor specifically consents. Gillian Haddow et al., Generation Scotland Preliminary Consultation Exercise 2003-2004: Public and Stakeholder Views from Focus Groups and Interviews, available at $\mathrm{http}: / / 129.215 .140 .49 / \mathrm{gs} / \mathrm{documents} /$ initialconsultation.pdf; see also Haddow et al., supra note 9.

39. Rao, supra note 9, at 372 .

40. Moore v. Regents of the Univ. of Cal., 793 P.2d 479 (Cal. 1990).

41. The majority reasoned that recognizing a property right would unnecessarily hinder medical research. See Bregman-Eschet, supra note 25, at 25 for a full discussion of arguments against granting individuals' property rights in their biological specimens and genetic informa- 
Greenberg v. Miami Children's Hospital ${ }^{42}$ followed Moore's nonbinding decision, rejecting recognition of an individual property right in excised specimens or in a derivation of one's gene sequence. In Greenberg, donors of human tissue and fluids, physicians doing research on Canavan disease, and private organizations sued physician, Dr. Reuben Matalon, a physician who obtained and licensed a patent for a gene causing the disease. Consistent with Moore's rejection of individual interests, Greenberg held that the gene patent for Canavan disease conferred a property right to researchers and hospitals, but not to the donors whose DNA contained this gene. ${ }^{43}$ Greenberg also implicitly rejected the equity concern of ensuring that specimen donors can benefit or obtain access to any research discoveries resulting from their donations. In this case, the individuals and family members who had donated tissue to Dr. Matalon to study Canavan disease were in some instances unable to obtain the screening test Dr. Matalon developed due to its high cost. ${ }^{44}$

Washington University v. Catalona ${ }^{45}$ followed the Greenberg ownership precedent, holding that once an individual donates specimens to a research institution, the individual no longer has any legal property claim to the specimens that would allow the individual to redirect or transfer the specimens. ${ }^{46}$ In Catalona, Washington University sought a court's declaration that it owned specimens collected for prostate cancer research so that it could prevent the donors of those specimens from transferring them to another research facility with a particular researcher, Dr. Catalona. ${ }^{47}$ The court in Catalona also affirmatively supported the research institution's right to the specimens over the rights of individual researchers. ${ }^{48}$

The court in Tilousi v. Arizona State Board of Regents ${ }^{49}$ similarly declined to recognize the ability of an individual to control the use of a specimen after donation, and it resolved questions related to research breadth in favor of the institution. ${ }^{50}$ In Tilousi, members of the Havasupai tribe objected to the researchers' use of genetic samples that they donated specifically for diabetes research, but which researchers used to study schizophrenia and inbreeding. ${ }^{51}$ According to members of the tribe, they would not have initially provided the donations if they had known that the researcher would carry out stigmatizing research to which they had not consented.

tion; see Moore v. Regents of the Univ. of Cal., 793 P.2d at 492-495; see also Rao, supra note 9 , at 372 .

42. Greenberg v. Miami Children's Hosp. Res. Inst., 264 F.Supp.2d 1064, 1074-75 (S.D.

Fla. 2003).

43. Id.; see also Rao, supra note 9, at 372.

44. Greenberg, 264 F.Supp.2d at 1067.

45. Washington Univ. v. Catalona, 490 F.3d 667, 675 (8th Cir. 2007).

46. Id. at $667,675-77$.

47. Id. at 672 .

48. Id. at 674-75.

49. Id.

50. Tilousi v. Ariz. State Bd. of Regents, Order no. 04-CV-1290-PCT-FJM (2004).

51. Id. 
Currently, only one case departs from judicial precedent favoring institutions, but the outcome is consistent with prior decisions in Moore, Greenberg, and Catalona in that the court seeks to maximize research using donated specimens. In Cornyn v. Fifty-Two Members of the Schoppa Family, ${ }^{52}$ members of the Schoppa family sought to ensure that the specimens of brains from their deceased family members and other genetic samples were actually put to constructive use for Alzheimer's research. ${ }^{53}$ In this case, the university to which they donated the tissues had halted their research efforts. While Cornyn was more favorable to the plaintiffs, the court's decision only held that the plaintiffs had standing to bring their claim for enjoining the destruction of the materials that they or their family members had donated. ${ }^{54}$

As the preceding cases demonstrate, current jurisprudence rejects several of the issues some members of the public believe to be important, such as the recognition of an individual's ability to place limitations or conditions on his or her donation. ${ }^{55}$

Additional concerns arise in the context of downstream products. Donors to biobanks generally want assurances that they will benefit from any screening tests, treatments, or medications developed through research using their donations, and they do not always trust the institution to ensure reasonable access. Once researchers have patented a cell line, the current legal framework allows the patent holder to sit on the patent where the holder would not develop useful continuing research of the cell line or develop a product such as a genetic screening test for the patented cell line. A patent holder's exclusionary rights would also prevent other researchers from using the patented cell line to develop further technologies. ${ }^{56}$

In several situations where researchers have patented a downstream product developed from donated biological materials, the donors themselves have been unable to benefit from the technological advancement. ${ }^{57}$ This exclusion of

52. Cornyn v. Fifty-Two Members of the Schoppa Family, 70 S.W.3d 895 (Tx. Ct. App. 2001).

53. Id. at 900-01.

54. The court in Cornyn did not directly rule on the issue of whether the donors could actually prevent the destruction of their tissues, nor did the court rule that the donors could require constructive use of their tissues. Id.

55. Rather than participating in research through the current institutional framework like in Tilousi, PXE created their own contractual model whereby they created a biobank and enter into written agreements with researchers who submit to PXE's conditions. See Kevin Oberdofer, The Lessons of Greenberg: Informed Consent and the Protection of Tissue Sources' Research Interests, 93 GEO. L.J. 365, 390-91 (2004).

56. Pilar Ossorio proposed to address this potential technological stall by stipulating that if patent holders sat on their patent, they could be legally required to license their patents to entities that would constructively develop further technology. Pilar Ossorio, The Human Genome as Common Heritage: Common Sense or Legal Nonsense? 35 J.L. MED. \& ETHICS 425, 435 (2007). (2005).

57. See Lori Andrews, Harnessing the Benefits of Biobanks, 33 J.L. MED. \& ETHICs 22, 22 
benefits poses a serious concern to previous donors and, if not addressed, could hinder future willingness to donate. ${ }^{58}$

\section{Implications of the Current Regulations on Biobank Research}

Although the current legal and regulatory environment for biobank research is confusing and sometimes inconsistent, there are some positive implications for states that choose not to legislate further, but to rely on the legal status quo. As noted above, current regulatory ambiguities have been interpreted in favor of the research institution and allow institutions greater control over donated specimens. Federal regulations may be revised, and those revisions might reconcile the current inconsistencies. However, the status quo also has troubling implications for biobank research. The regulatory ambiguities and inconsistencies hinder efficiency by chilling some researchers and IRBs, who would be more likely to engage in research or approve protocols if there were clear guidance regarding how to do it legally. Long-term public support may be adversely affected when people learn about the amount of research that takes place outside federal regulatory supervision and IRB oversight. The status quo also fails to allay the public's fears regarding genetic discrimination. Finally, the uncertainty about tissue ownership potentially decreases investment in biobank-related research due to fears of litigation over downstream products. Some disease advocacy groups, distressed over the ways in which courts have resolved these disputes, have turned to negotiating contracts with researchers that give them intellectual property rights in commercial products; such ad hoc contract negotiations, however, undoubtedly have an adverse effect on efficiency.

\section{E. Ethical Considerations}

States considering whether to accept or attempt to change the status quo regarding biobank research may wish to consider the question in the context of three important ethical norms: the value of advancing medicine and improving health; respect for autonomy (or respect for persons); and the protection of privacy and confidentiality. In typical biomedical research, the process of obtaining informed consent (or refusal) requires "disclosure[s] about the purpose, risks, benefits and protections for confidential information [which] provide[s] participants with the opportunity to exercise autonomy by choosing to partici-

58. One way to address this concern is to create a regulatory provision that could ensure donors have free access to tests, treatments, or medications developed from their donations. See Melanie Baird, When and Why Does What Belong to Whom? A Proposed Model for the International Protection of Human Donors of Biological Material, CAN.-U.S. L.J. 331, 345 (2006). Iceland's agreement with deCode Genetics contained a similar provision which allowed Icelanders free access to drugs developed by deCode for the duration of the patent period. See Rao, supra note 9 , at 375 . 
pate in the study of a drug or device.." ${ }^{, 59}$ The presentation of this information allows research participants to weigh the relative importance of these sometimes conflicting values themselves. The traditional paradigm is complicated in cases of research originating in biobanks, which are "research platforms that may involve hundreds of different research initiatives spread over a long period of time. ${ }^{, 60}$ It therefore becomes difficult, expensive, and sometimes impossible to obtain informed consent for specific projects. In addition, the vast number of collaborative arrangements between the researchers who first collect data or tissues, and the subsequent users of that information, severs the relationship between researchers and tissue donors, and sometimes removes the research from federal regulatory oversight.

The first important value is that of advancing medicine and improving health, which can be best accomplished by laws and procedures that maximize the efficiency of the process of collecting and using biological samples and data, and allows the greatest access possible to richly annotated samples. The promise of this kind of research extends to nearly every area of medicine, from personalized clinical therapy to broad-based public health efforts, and it is also presumed to serve the economic interests of the community by creating jobs. However, it is possible that an overly vigorous pursuit of research efficiency can backfire, particularly if this goal is pursued in ways incompatible with respect for individual choice and protection of donors from potentially discriminatory uses of their information. For example, researchers collecting biological samples were seen as exploitative of indigenous peoples in Alaska. ${ }^{61}$ Alaska responded with a set of laws so protective of donors that it is unlikely that Alaska would ever be capable of fostering a robust genetic research agenda. ${ }^{62}$

The second important value is respect for autonomy, which concerns the long-standing legal and ethical norm that individuals have the right to make important choices about their own lives. A robust understanding of respect for autonomy focuses on the well-informed choices of individuals with regard to the research uses of information and/or tissue samples. For instance, individuals may affirmatively choose to participate in certain kinds of research (such as breast cancer or Alzheimer's disease) or purposefully avoid potentially stigmatizing research or research that is morally objectionable for more idiosyncratic reasons (such as religious or philosophical objections to certain practices). Some argue that the robust conception of autonomy is not relevant in the case of research involving tissue samples because the donors of those samples (and the corresponding information related to them) are not human research subjects

59. Timothy Caulfield, Russell Brown, \& Eric M. Meslin. Challenging a Well Established Consent Norm? One Time Consent for Biobank Research, 4 J. INT'L BIOTECH. L. 69, 70 (2007).

60. Id. at 70 .

61. Brett Shelton, Consent and Consultation in Genetic Research on American Indians and Alaska Natives, Indigenous Peoples Council on Biocolonialism, http://www.ipcb.org/pub lications/briefing_papers/files/consent.html (last visited Mar. 17, 2008).

62. AlaSKA STAT. $\S \S 18.13 .010 \& 18.13 .030(2008)$. 
in the classic sense. ${ }^{63}$ However, for those who believe that respect for autonomy continues to be important after tissue collection, there is a kind of ethical zero-sum game; increasing individual control decreases the efficiency and value of the genetic research that can be done.

A third important ethical value implicated by genetic research is the responsibility to protect the privacy and confidentiality of individuals' health information in order to guard against insurance and employment discrimination. This has been the focus of many state genetic privacy laws. ${ }^{64}$ Georgia's state laws, for example, are structured to limit the use and availability of genetic information and prevent certain disclosures of genetic information to third parties. $^{65}$

\section{STATE APPROACHES TO FEDERAL REGULATORY INCONSISTENCIES IN GENETIC RESEARCH}

Part III describes how some state legislatures have addressed the inconsistencies in federal law. This portion of the Article first describes state legislatures' definitions of legal elements involved in the process of collection, research, usage, and storage of specimens and genetic information. Next, this section describes how several states have adopted a mutually exclusive approach to legislation: either increasing research efficiency by decreasing autonomy and privacy for individual donors or increasing individual protections at the expense of research efficiency.

\section{A. State Legislative Responses: An Overview of Legal Elements}

Several states have attempted to clarify the uncertainty in the federal regulatory framework by defining relevant terms related to the biobanking and genetic research process. The following is a summary of several existing state laws relating to the collection of biological specimens or genetic samples, storage of genetic samples, and retention of genetic samples and genetic information. These provisions do not apply to genetic testing or analysis conducted in other contexts such as criminal identification purposes, paternity testing, or newborn screening. ${ }^{66}$

63. Greenberg v. Miami Children's Hosp. Research Inst., 264 F.Supp.2d 1064, 1069 (S.D. Fla. 2003).

64. See Ga. Code ANN. §§ 33-54-1 to 33-54-8 (2007); LA. Stat. ANN. 22:213.7 (2008); but see N.M. STAT. ANN. § 24-21-3 (West 2008).

65. Id.

66. It is important to note that states may differ in the way they define basic terms such as "DNA samples" or "genetic information", and those definitions may affect the way a law is interpreted. For example, Oregon defines a DNA sample as the biological specimen collected for the purpose of extracting and analyzing DNA as well as the actual DNA extracted from the sample. This definition affects how one would interpret a law which gives the requirements to collect a DNA sample because that collection could mean obtaining a blood sample or extracting 


\section{Personal Access to DNA Results}

If a physician or researcher is performing a genetic test or analysis, some states include provisions which describe how that information may be provided to the individual. For instance, when signing the informed consent form to obtain a genetic sample and analysis, Delaware requires that the person obtaining the sample provide the individual with the results of the analysis unless the individual directs otherwise. ${ }^{67}$ Some states also require that informed consent forms contain a request provision which allows an individual who contributed a sample for DNA analysis to request, inspect, or obtain his or her own genetic records. $^{68}$

\section{Informed Consent and Exemptions}

States vary widely with regard to informed consent requirements for the collection, use, or retention of a genetic sample and genetic information. Several states have exempted persons from obtaining informed consent before procuring genetic information for medical repositories or medical and scientific research. New Mexico provides that an individual's DNA, genetic information, or a genetic analysis may be obtained, retained, transmitted, or used without a person's written informed consent pursuant to federal regulations if that information is for a medical repository or registry, or medical or scientific research. ${ }^{69}$ Nevada law also provides a similar exception, which states that if a researcher obtains the genetic information for use in a study where the identities of the individuals are not disclosed to the person conducting the study, then the individual's informed consent to obtain that genetic information is not required. ${ }^{70}$

Oregon has created an "opt-out" notification system for researchers to collect coded or identifiable samples without obtaining written informed consent provisions. A researcher must notify the individual that his or her biological specimen or individual identifiable health information will be used for coded or anonymous research, and that the researcher may use the genetic sample and genetic information unless the individual responds to the notice indicating that he or she does not want the sample or information used. ${ }^{71}$ Researchers are not required to obtain any consent for collection or use of a DNA sample or genetic information which is de-identified or unidentified; they are also not required to provide individual notice when samples will be de-identified. ${ }^{72}$

Alaska law requires a researcher to obtain written informed consent before collecting an individual's DNA sample, performing a DNA analysis on that

the DNA in a laboratory setting.

67. Del. CODE ANN. tit. 16, $\S 1220$ (2008).

68. Alaska Stat. § 18.13.010 (2008); Del. Code ANN. tit. 16, § 1223 (2008); NeV. ReV.

STAT. § 629.141 (2008); OR. REV. STAT. § 192.537 (2008).

69. N.M. STAT. ANN. § 24-21-3 (West 2008).

70. NeV. REV. STAT. $\$ 629.151$ (2003).

71. OR. REV. STAT. $\S \S 192.537-192.538$ (2003).

72. OR. REV. STAT. $\S 192.537$ (2008). 
sample, retaining a DNA sample or the results of the DNA sample, or disclosing the results of the DNA analysis. ${ }^{73}$ Some state laws specify that separate informed consent must be obtained for each action. Delaware law outlines specific elements to satisfy the informed consent requirements. ${ }^{74}$ To obtain consent for collection of a non-anonymous sample and to obtain a genetic analysis, Delaware requires the informed consent form to list a description of which genetic tests will be performed, their purposes, potential uses, limitations, and the meaning of the results, as well as providing the individual with the test results unless the individual directs otherwise. Delaware law also requires that the retention portion of the informed consent form include a description of the genetic information retained and its potential uses and limitations. To disclose genetic information, the statute requires that the informed consent form provide an additional description of the information released and to whom it may be released. ${ }^{75}$

\section{Retention and Destruction of DNA Samples and Genetic Information}

States vary widely with regard to researchers' ability to retain an individual's genetic sample and information, as well as whether a researcher is required to destroy an individual's genetic sample upon request. Several states specify the disposition of the genetic samples and/or genetic information in circumstances where an individual has not specifically requested sample destruction. In Nevada, when an individual does not specifically request destruction of genetic information, the researcher must destroy the genetic information either after the completion of the study or after the individual withdraws from the study ${ }^{76}$ In New Mexico and Oregon, a DNA sample from an individual that is used for non-anonymous research must be destroyed upon the completion of the project or if the individual withdraws from the project. ${ }^{77}$

Some states, however, include a provision for continued use and retention of the genetic information and sample. Nevada and Oregon law allows researchers to retain genetic information after completion or withdrawal from the study by obtaining specific authorization from the individual. ${ }^{78}$ The New Mexico statute also stipulates that an individual's genetic samples and genetic information must be destroyed at the individual's request, but this provision contains many significant exceptions. The individual's right to request destruction does not apply where an individual's samples are used by an IRB-approved research protocol, if the samples are being used by an authorized medical repo-

73. Alaska Stat. $§ 18.13 .010(2006)$.

74. Del. CODE ANN. tit. $16, \S 1220$ (2008).

75. Id.

76. See NEV. Rev. STAT. $§ 629.161$ (2000).

77. See N.M. Stat. ANN. $§ 24-21-5$ (West 2008); OR. Rev. Stat. $§ 192.537$ (2003).

78. NEV. ReV. STAT. § 629.161 (2000); Or. ReV. STAT. § 192.537 (2003). 
sitory or registry, or for other medical or scientific research. ${ }^{79}$ Oregon law similarly recognizes an individual's general right to request destruction of a DNA sample, but specifies that this right does not apply to samples retained for coded or anonymous research samples collected from an individual who did not previously opt-out. ${ }^{80}$

Alaska and Delaware statutes further clarify that a person must obtain informed consent from an individual to retain a genetic sample or genetic information. ${ }^{81}$ In Delaware, however, consent is not required if the sample is used for anonymous research. ${ }^{82}$ Delaware law requires researchers to comply with an individual's request to destroy genetic samples, unless retention has been previously authorized by the individual or the sample is used for anonymous research where the identity of the individual will not be released. ${ }^{83}$ In Nevada, if an individual requests that a researcher destroy genetic information, the researcher must comply with that request. ${ }^{84}$

\section{Disclosure of Results}

State laws vary regarding the disclosure of genetic information to third parties, the process of disclosure, and limitations on disclosure. New Mexico law expressly prohibits an insurer from discriminating against a person or a member of the person's family on the basis of genetic analysis, genetic information, or genetic propensity. ${ }^{85}$ Despite this provision, New Mexico does not prohibit the use of genetic analysis, genetic information, or genetic propensity by an insurer in the ordinary course of business in connection with life, disability income, or long-term care insurance if the information is based on sound actuarial principles. ${ }^{86}$

Georgia law requires that an individual's genetic information be kept confidential and may be released only to the individual and specific persons authorized by the individual. ${ }^{87}$ When a researcher obtains informed consent for the DNA analysis of the sample, the law specifies that this consent only allows the researcher to use the genetic information for the authorized research study, eliminating the possibility that the researcher could share or transfer the individual's genetic information to a party outside of the research study. ${ }^{88}$

Several states impose conditions for the release of genetic information to parties like insurance providers and specify actions prohibited by insurers who

79. See N.M. STAT. ANN. $\S 24-21-5$ (West 2008).

80. OR. REV. STAT. $§ 192.537$ (2003).

81. Alaska Stat. § 18.13.010 (2006); Del. Code ANN. tit.16, § 1222 (2008).

82. Id.

83. Del. Code ANN. tit. 16, § 1222 (2008).

84. Nev. Rev. StAT. $\S 629.170(2000)$.

85. N.M. STAT. ANN. § 24-21-4 (West 2008).

86. See N.M. STAT. ANN. $\S \S 24-21-3-24-21-4$ (West 2008).

87. GA. CODE ANN. § 33-54-3 (2008); accord ALASKA STAT. § 18.13 .010 (2008).

88. GA. CODE ANN. § 33-54-6 (2008). 
obtain this information. Several states allow an individual to release his or her genetic information to insurers by means of an informed consent provision. Delaware law, for example, requires consent for the release of genetic information to an insurer, and the insurer can retain the information only for the specific purpose and specific length authorized by the individual. ${ }^{89}$ Georgia law prohibits insurers from using released genetic information for any nontherapeutic purpose. ${ }^{90}$

Even some of the state laws that are framed as preventative measures against disclosure of genetic information contain significant exceptions. Oregon's opt-out scheme allows any health care provider covered under HIPAA to disclose genetic samples or information for coded or anonymous research so long as the provider provides the individual with notice of the research and an opportunity to decline participation. ${ }^{91}$ If the health care provider is not a HIPAA-covered entity, the health care provider is not required to inform the individual of plans to disclose the genetic sample or protected health information for coded or anonymous research process. ${ }^{92}$ Oregon law also provides that the publication of an individual's genetic information or identity does not constitute a disclosure if it is not due to willful neglect and if it is corrected before a third party learns of it or performs a genetic test on a tissue sample. ${ }^{93}$

Florida law requires the individual's consent to disclose the results of genetic information, but the law also states that the health care provider must provide the individual with notice if the genetic information is used in any decision to grant or deny any insurance, employment, mortgage, loan, credit, or educational opportunity, suggesting that Florida law allows these decisions to be based on genetic information. ${ }^{94}$

\section{Property Interests}

Few state laws address ownership issues related to genetic material or information. Five states define DNA analysis test results as the exclusive property right of the individual..$^{95}$ Florida clarifies that this property right applies even if the results of the DNA analysis are held by a private entity. ${ }^{96}$ Oregon originally included in its law a definition of genetic information as the property of the individual, in "an attempt to solve several legal problems: providing guidance to the courts as to the nature of a person's rights to genetic information,

89. Del. Code. ANn. tit. $16, \S 1220$ (2008).

90. GA. CODE ANN. § 33-54-4 (2008).

91. See Or. Rev. StAT. § 192.538 (2003).

92. See id.

93. OR. REV. STAT. $\$ 192.539$ (2003).

94. Fla. Stat. ANN. $\S 760.40$ (West 2008).

95. See Alaska Stat. $§ 18.13 .010$ (2006); Colo. Rev. Stat. AnN. $§ 10-3-1104.7$ (West 2008); Fla. STAT. ANN. $§ 760.40$ (West 2004); GA. Code ANN. § 33-54-1 (2008); LA. REV. STAT. ANN. 22:213.7 (2008).

96. See Fla. Stat. ANN. $§ 760.40$ (West 2004). 
allowing family ownership of genetic information, and implying a remedy for a blood relative of an individual who suffers discrimination." ${ }^{, 97}$ It was later repealed because, according to a pharmaceutical company, it negatively impacted research due to concerns that "a subject of research might later assert a claim to own the fruits of research and that a transfer of those rights to a researcher might be unenforceable." 98

In addition to the results of the DNA analysis, Alaska is currently the only state to have a law that defines the actual DNA sample as the "exclusive property" of an individual. This severely or completely limits the possibility of using one's genetic sample as the basis for a commercial product development. ${ }^{99}$

\section{Civil and Criminal Liability}

States vary as to how, if at all, they address violations of the provisions discussed above. States recognizing a person's liability for violating these statutes vary with regard to which individual (or individuals) has standing to bring a claim, who may be named as a breaching party, what applicable law an individual may use to claim a breach or injury, and what damages the law makes available to complaining parties. "Standing" is defined as "a person's right to make a legal claim or seek judicial enforcement of a duty or right." "100 Standing refers to who can claim an injury by a physician or researcher's violation of the statutes relating to genetic samples and information. Some states, such as Alaska, define standing broadly, stating that "a person" may bring a claim. ${ }^{101}$ New Mexico law specifies that "a person whose rights have been violated under the provisions" has standing, ${ }^{102}$ but it also permits the attorney general or district attorney to initiate a civil action against a person for violations. ${ }^{103}$ Nevada defines standing so that it includes "any person who suffers an injury as a result of the disclosure," explicitly expanding "standing" to more than the original genetic sample contributor. ${ }^{104}$

The term "breaching party" refers to a person or entity who owes a legal duty to another person, and in violating that duty, has caused injury or harm to another person. ${ }^{105}$ In this context, the breaching party may be the physician, researcher, or institution that has a duty to the patients and participants to uphold and follow state laws when obtaining and using genetic samples and information. If physicians or researchers do not follow these requirements, then

97. History of Oregon's Genetic Privacy Law, http://egov.oregon.gov/DHS/ph/gene tics/docs/History_of_Oregon2_07b.pdf, 2005, at 2 (referencing S.B. 276).

98. Id.

99. Alaska Stat. § 18.13.010 (2006).

100. BLACK'S LAW DICTIONARY 1442 (8th ed. 2004).

101. Alaska Stat. $\$ 18.13 .020(2006)$.

102. N.M. STAT. § 24-21-6(B) (2008).

103. N.M. STAT. § 24-21-6 (2000).

104. NEV. ReV. STAT. §629.201 (2008).

105. See generally “breach,” BLACK's LAW DiCTIONARY, supra note 100, at 200. 
they are breaching this duty. Many of the states that allow civil relief define breaching party as "any individual" or "any person" who retains, obtains, or discloses an individual's genetic sample or genetic information. ${ }^{106}$ States vary on the level of intent, if any, required to show a violation of these laws. Generally, intent is defined as a person's state of mind accompanying a certain act. This mental state may range from negligence to knowingly and willfully violating a law. Several states rely on a strict liability standard with regard to intent, where the law recognizes a violation regardless of the person's state of mind. For example, laws in Alaska and New Mexico specify that any violation of their statutes constitutes a potential claim. ${ }^{107}$ Delaware law requires an element of intent, and the individual bringing the claim must demonstrate that the person "willfully" violated the statutory provisions. ${ }^{108}$ In Oregon, there is a tiered system based on levels of the alleged violator's knowledge and intent, ranging from inadvertent violations to those knowingly committed. ${ }^{109}$

Oregon is the only state that specifically allows the breaching party to use an affirmative defense. ${ }^{110}$ An "affirmative defense" is an argument which allows the breaching party to defeat the injured party's claim, even if all of the alleged violations are true. ${ }^{111}$ For example, a patient may allege that a researcher disclosed the patient's genetic sample and information to a third party, which would theoretically violate the law. Nevertheless, even if the researcher did breach a duty, the researcher could demonstrate that he or she took action to correct the violation. A court may accept that the researcher satisfied the requirements of an affirmative defense by taking corrective action and rule in favor of the researcher. This provision would allow a researcher or institution opportunities to correct violations, which would decrease a patient's potential success in legal disputes.

If a court finds that a person has violated the provisions of the law, the injured party may be entitled to damages. Damages are usually monetary in nature, paid by the breaching party to the injured to compensate that person for his or her injury. Some states specify the type of damages or the amount of monetary damages an injured individual may recover if successful. Nevada law states that an individual is entitled to actual damages, ${ }^{112}$ while Oregon's tiered system specifies dollar amounts, which the court may award for each particular violation. ${ }^{113}$ Some states, such as Georgia, mandate breaching insurers to pay actual damages or the court may order the insurer to provide the individual insurance coverage under the same terms had the violation not occurred. ${ }^{114}$

106. Id.

107. Alaska STAT. $\S 18.13 .020$ (2006); N.M. STAT. $\S 24-21-5$ (2008).

108. Del. CoDE ANN. tit. 16, § 1227 (2008).

109. OR. REV. STAT. § 192.541 (2003).

110. See id.

111. BLACK's LAW DictionaRY, supra note 100, at 451.

112. NEV. REV. STAT. § 629.201 (2000).

113. OR. REV. STAT. \$ 192.541 (2003).

114. GA. CODE ANN. § 33-54-8 (2008). 
Very few states recognize criminal liability for violations of the laws referenced above. ${ }^{115}$ Florida law states that a violation constitutes a Class A misdemeanor, ${ }^{116}$ while the laws in Alaska and Oregon specify that a level of intent is required to find a violation, such as the person knowingly or recklessly violated the corresponding statutory provisions. ${ }^{117}$

\section{B. State Legislative Strategies to Protect Donors or Promote Research Efficiency}

State legislatures that appear to have a conscious strategy regarding genetic research tend to pass laws that, in combination, either promote research efficiency, potentially at the behest of medical and pharmaceutical interests, or to enhance donor protections.

\section{State Laws that Increase Protections for Tissue Donors}

Some states have passed legislation that treat the collection of tissue and its related information just like other kinds of human subjects research. This means that informed consent is required to obtain an individual's samples and to perform genetic tests for research, but no attempts are made to streamline the consent procedures or requirements for the unique difficulties in research involving biobanks and data repositories.

Several states follow the traditional human subjects research model of obtaining informed consent for every collection and subsequent research procedure, yet the states provide exceptions for anonymous research. For example, Delaware requires a physician or researcher to obtain the patient's written informed consent for the sample collection, sample genetic analysis, and storage of the genetic sample, if the research is not anonymous. ${ }^{118}$ Florida defines a patient's genetic information as his or her personal property, although this element of the law focuses on protecting the patient's confidentiality and preventing unauthorized disclosure and does not confer rights to direct the use of tissue or profit from commercial products. ${ }^{119}$ This model protects patients and donors from unwanted collection or unauthorized genetic research of their samples, but may not allow for maximum sample collection if the repository wishes to con-

115. See infra, notes113-115 and accompanying text.

116. FLA. STAT. ANN. $§ 760.40$ (West 2004).

117. Alaska Stat. $\S 18.13 .030$ (2006); OR. ReV. STAT. $\$ 192.543$ (2003).

118. Del. Code ANN. tit. 16, § 1221-1222 (2008).

119. See Greenberg v. Miami Children's Hosp., 264 F.Supp.2d 1064, 1069 (S.D. Fla. 2003). The court in Greenberg cites Section 760.40 of the Florida statute, which states that individuals contributing tissue for researchers do not relinquish ownership of the results of the analysis. The court limited the application of this provision by holding it did not extend to any right relating to the development of commercial products, because the donors severed their interest upon donating their tissues. Greenberg, 264 F.Supp.2d at 1069. 
duct coded research. ${ }^{120}$ Ensuring full informed consent for the collection of the biological specimen and all its genetic research uses may be costly, time consuming, and logistically complicated. Some donors may also be hesitant to authorize use of their samples if they are re-contacted by researchers, which could result in a loss of samples for continued use.

Oregon has enacted laws that provide even greater protections for individuals. Oregon's laws are generally consistent with federal regulations. There is, however, one important exception: individuals must have the opportunity to opt-out of anonymous or coded genetic research otherwise allowable in some circumstances under federal law. ${ }^{121}$ If patients do not respond to the notice in the allotted time period of six months to indicate that they do not want the sample or information used, then the physician or researcher may retain and use the sample and information. If patients do not choose to opt-out, the tissues may be used for anonymous or coded research approved or exempted from approval by an IRB. Interestingly, although Oregon's law gives patients more protections than the federal regulations, much of the public response has been negative, because the public has realized for the first time that their health information or biological specimens can be used without their consent. This is one gap in education that Oregon's Advisory Committee on Genetic Privacy and Research ("Oregon's Advisory Committee") is attempting to remedy. ${ }^{122}$ Since this requirement became law in Oregon, it has caused some confusion in terms of how providers should present this information, and how laboratories can track samples of those who have opted out. ${ }^{123}$ The donor opt-out model requires an informed public to work properly, and Oregon has created an Advisory Committee on Genetic Privacy and Research that has developed educational tools for IRBs, researchers, and health care consumers. ${ }^{124}$

Alaska is the most restrictive state with regard to the collection and storage of a patient's genetic sample and information and strongly favors individual rights. Alaska is the only state which defines an individual's genetic sample as his or her personal property. Alaska and Florida follow the consent requirements imposed in states like Delaware, but importantly require informed con-

120. Some states do not require consent for research using anonymous specimens. Although this is not recognized by federal law as human subjects research, it does not technically protect patients from all unwanted collections and uses of their specimens. See DEL. CODE ANN. tit. 16, § 1227 (2008); N.Y. CIV. RighTS LAW § 79-1 (McKinney 1997). But see AlaSKa STAT. § 18.13.010 (2006); FLA. STAT. ANN. $§ 760.40$ (West 2004) (language of statutes do not contain exemptions to use anonymous specimens for genetic research).

121. OR. REV. STAT. § 192.535(1)(b) (West 2007).

122. REPORT TO THE LEGISLATURE ASSEMBLY, AdVISORY COMMITTEE ON GENETIC PRIVACY AND RESEARCH 6 (Mar. 2007), http://egov.oregon.gov/DHS/ph/genetics /docs/ACGPR_030507.pdf [hereinafter OREGON's ADVISORY COMMITTEE]. The Oregon statute states that coded or anonymous research thought to be exempt must be officially submitted to the IRB for exemption and the IRB may exempt this research from review. OR. REV.STAT. $\S$ 192.547(2) (West 2003).

123. OREGON'S ADVISORY COMMITTEE, supra note 122, at 7.

124. See id. at 8. 
sent even if research is anonymous. Alaska's strict laws are a response to several historical breaches of research ethics involving the indigenous population, such as the Human Genome Diversity Project and the Genographic Project. ${ }^{125}$

These approaches are diverse, but they all attempt to provide patients and tissue donors with greater control over what happens to their tissues. The requirements for informed consent extend to all researchers, not just those who are federally regulated, which closes a significant loophole. Patients and donors can therefore feel that they are more in control of whether and how their biological specimens are used. In addition, they have corresponding control over the privacy of their information, at least to the extent that they can refuse to donate to research.

Exactly how these additional protections would impact research efficiency is, in the end, an empirical question. Still, it is worth speculating, particularly when states are keen to attract life sciences companies. With these additional protections, research efficiency is partially subordinated to respect for autonomy and protection of privacy. Depending on the state's response, researchers would find additional requirements to obtain informed consent in cases in which it was previously unnecessary. Delaware's law, for instance, would impose many of the same hurdles that already exist, such as finding people to obtain consent, ensuring that people read their mail to find out what's happening, and the loss of samples to people who become annoyed by being recontacted, but who otherwise do not object. In addition to these barriers, Oregon faces the additional hurdle of providing notice to all health care providers of the legislative changes so that health care providers and clinics can adapt to these new laws. Additionally, monitoring patient opt-out requests is challenging for laboratories (particularly when samples are sent from one lab to another), and the costs of notifying consumers is significant (but it is not quantified in the Committee's 2007 Report). ${ }^{126}$ In Alaska, the barriers to conduct genetic research may be insurmountably high. Consent is required even for anonymous research, and ownership rights remain with individuals even, it would seem, after commercial products have been developed. ${ }^{127}$

It is also not clear how these additional protections would affect public support of the research agenda of biobanks. Anecdotal data from Oregon suggests that consumers are dissatisfied that they are required to opt-out of certain kinds of genetic research, rather than affirmatively choosing to participate. ${ }^{128}$ This data reveals that the public does not understand that its health information and biological samples are already used without consent in some circumstances

125. Brett Shelton, Consent and Consultation in Genetic Research on American Indians and Alaska Natives, Indigenous Peoples Council on Biocolonialism, http://www.ipcb.org /pulications/briefing_papers/files/consent.html (last visited Mar. 17, 2008); Declaration of Indigenous Peoples of the Western Hemisphere Regarding the Human Genome Diversity Project, http://www.tebtebba.org/tebtebba_files/susdev/bdv/iphgdp.html (last visited Mar. 18, 2008).

126. See OREGON'S ADVISORY COMMITTEE, supra note 122.

127. Alaska Stat. $\S 18.13 .010$ (2006).

128. OREGON'S ADVISORY COMMITTEE, supra note 122, at 7. 
under federal law. Although Oregon citizens receive additional protections under their genetic privacy and research laws, they may become more suspicious and less supportive of research in general. Therefore, on the one hand, it is entirely possible that public support of biobank research will decrease, because people have a better understanding of what little protections they actually have. On the other hand, it is possible that over time, Oregon citizens will support genetic research because they trust the researchers and feel that they have some control over the research projects that are undertaken.

The range of patient protections in this area provides insight on several factors regarding the balance of efficiency and public involvement from which states may benefit. Failing to inform the public and earn the public's trust has resulted in either restrictively reactive laws or laws with which the public may not fully understand or agree. Both responses, either fully protecting individual rights or only recognizing increased individual protections for certain types of research, impede efficiency when the laws are not balanced with a mechanism to streamline the research process for donors who do provide consent.

\section{State Laws that Promote Research Efficiency}

Some states resolve the federal regulation's ambiguity in favor of promoting research efficiency, but in a way that provides limited usefulness for the development of translational medicine. These states create extensive exceptions that allow a researcher or physician ${ }^{129}$ to obtain, store, and use biological specimens and medical information under federal regulatory exemptions, such as IRB waivers, or under a "medical or scientific research" exemption. ${ }^{130}$ When collecting a sample under these laws, the researcher does not need to obtain actual informed consent explaining that the sample will be used for research or stored in a repository. These laws also do not restrict the research to OHRP's enumerated uses but rather allow researchers to store the genetic sample and information in a biobank for future unspecified uses or to use them in a specific research project. ${ }^{131}$ For example, this type of law would allow a re-

129. For the sake of brevity, the authors refer to the person obtaining, using, and retaining the genetic samples as the "researcher" or "physician." Many statutes use the general term "person," which, in addition to a physician or researcher, could include nurses, lab technicians, research institutions, and hospitals. The authors also use the term "patient" or "participant" to indicate the person donating the sample for genetic research. Many statutes provide only a general definition of "individual" when referring to the person donating the sample. Individual state statutes should be consulted to determine the precise definition of each term in a particular state.

130. N.M. Stat. ANN. § 24-21-3 (West 2008); NeV. Rev. Stat. AnN. 629.151 (West 2000); NeV. ReV. Stat. ANN. 629.181 (West 2008).

131. This appears to be in conflict with federal guidance suggesting that merely collecting a human biological sample constitutes a single research activity, and any subsequent use of that tissue constitutes an additional research activity requiring separate consent. See Barnes \& Heffernan, supra note 18 , at 446. 
searcher to collect a biological specimen for future biobank use without obtaining the patient's informed consent.

Laws that enumerate informed consent exceptions are the most permissive and promote the use of genetic materials in research by exempting medical or scientific researchers from obtaining informed consent to store samples in a repository or to use them for genetic research. Several states, such as New Mexico and Nevada, allow physicians and researchers to obtain, use, and retain a patient's genetic sample as long as the genetic sample is used for "medical or scientific research" 132 or the sample goes to a statewide repository. Some states that use this model, such as New Mexico, place conditions on the confidentiality protocol to ensure genetic samples are coded or anonymous. New Mexico also specifies that this exemption process must comply with relevant federal regulations. ${ }^{133}$

Through the statutory exemptions or IRB waivers, these state laws resolve federal law ambiguities in favor of research efficiency, increasing the volume of samples collected for research or storage by eliminating the obstacles and costs associated with obtaining consent for each use. However, despite its short-term research efficiency, this model has two substantial drawbacks for states hoping to support translational medicine. First, data from samples that have been collected without informed consent cannot be used to support FDA applications, with the possible exception of in vitro diagnostic devices under certain circumstances. ${ }^{134}$ Second, this model poses a high risk of public backlash because it promotes the importance of research advancements without obtaining the permission of individuals whose materials may be used, and without engaging the public to gain its informed support.

\section{INDIANA'S LEGISLATIVE OPTIONS}

Part IV describes current Indiana statutes involving genetic information. Indiana has very few laws related to this subject, and could benefit from further legislation regarding biological specimens and genetic information in biobanking research. However, arguably, none of the approaches discussed with previous state efforts strikes the right balance among the ethical values at stake.

132. The definition of "medical or scientific research" may differ from state to state. New Mexico states that medical or scientific research and education include the "retention of gene products, genetic information or genetic analysis if the identity of the person or person's family members is not disclosed" but does not explicitly preclude partnerships with private entities. N.M. STAT. ANN. § 24-21-3 (West 2008).

133. Id.

134. In its recent guidance, the FDA stated that it "does not intend to object to the use, without informed consent, of leftover human specimens . . . in investigations that meet the criteria for exemption from the Investigational Device Exemptions ("IDE") regulation at 21 C.F.R. 812.2(c)(3), as long as subject privacy is protected by using only specimens that are not individually identifiable." U.S. FDA, GUIDANCE ON INFORMED CONSENT FOR IN VITRO DIAGNOSTIC DEVICE STUDIES USING LEFTOVER HUMAN SPECIMENS THAT ARE NOT INDIVIDUALLY IDENTIFIABLE (2006), available at http://www.fda.gov/cdrh/oivd/guidance/1588.pdf. 
The respect for donor control and privacy protection that is gained in states like Delaware, Oregon, and Alaska come at a very high cost in terms of research efficiency. Attempts to facilitate research, represented by states like New Mexico, may risk a public backlash, and may be unable to support the most valuable kinds of translational research. ${ }^{135}$ The proposal here, therefore, recommends statutory provisions that demonstrate respect for the persons who may donate tissue to biobanks while also creating an environment that supports high quality translational research.

\section{A. Existing Indiana Law Related to Genetic Information}

\section{Repositories or Genetic Information Databases}

Neither the Indiana legislature nor the Indiana courts have addressed individual rights relating to DNA or genetic material in the research context. Indiana does have a DNA database for criminal identification and statistical purposes, ${ }^{136}$ but Indiana courts have only applied this law in the criminal context. $^{137}$

\section{Indiana Statutory Definitions of Genetic Testing; Insurance Coverage}

Indiana law defines genetic tests relating to insurance coverage and specifies that the definition only applies for the purposes of regulating certain categories of insurance coverage. ${ }^{138}$ The law defines genetic screening tests as tests to identify an individual's chromosomal abnormalities or carrier status to indicate susceptibility to a particular disease. ${ }^{139}$ Indiana law also prevents health care services organizations from basing the provision of health care services on these genetic test results. ${ }^{140}$ Indiana does not extend this definition or offer a similar definition for genetic testing for research purposes or genetic testing on individual samples removed from an individual and used within a biobank or repository setting.

135. Samples that are collected without informed consent will not have the rich annotation many researchers find indispensible to quality research as data from those samples cannot be used to support FDA applications, which is a key step in developing medical products.

136. See IND. CODE $§ 10-13-6-13$ (2007).

137. The Indiana case applies only within the criminal context for the purpose of perpetrator identification. Indiana case law has clarified the legal status of a criminal defendant's DNA. The Indiana Supreme Court held that once a defendant's DNA is used to create a profile for the databank, it becomes the property of the databank and the defendant has no possessory or ownership interest in the DNA profile. Smith v. State, 744 N.E.2d 437, 439 (Ind. 2001).

138. IND. CODE $§ 27-8-26-1$ (2008).

139. Id.

140. Id.; IND. CODE § 27-8-26-5 (2008). 
Indiana law provides that insurance companies may obtain the results of an individual's health records or medical information, which may include genetic screening or tests, with a separate written consent. ${ }^{141}$ If the insurance company inadvertently receives genetic information, the insurance company is not liable for failing to obtain the informed consent form. ${ }^{142}$ This provision does not apply to life insurance policies. ${ }^{143}$

Indiana also has specific provisions which prevent some adverse actions by insurance companies as a result of genetic testing. ${ }^{144}$ For instance, an insurer may not require genetic screening or testing, or consider any information obtained from genetic screening or testing in a manner adverse to the applicant or the applicant's family that would limit benefits or establish premiums for health insurance coverage. ${ }^{145}$ Additionally, in developing and asking questions regarding the medical history of an applicant for health care services coverage, an insurer may not ask for the results of genetic tests or ask questions designed to ascertain those results. ${ }^{146}$

These provisions do not apply to genetic testing on an individual's sample for research purposes, but rather are applicable to genetic screening tests for health care purposes. Unlike other state laws which explicitly prevent insurance companies or other parties from discriminating based on genetic information obtained during the research process. ${ }^{147}$ Indiana law is not clear on this issue.

\section{B. Approaches to Addressing Indiana's Lack of Legislation}

\section{Status Quo}

There are both positive implications as well as potential drawbacks from relying only on federal regulations from the perspective of Indiana's various life sciences initiatives. There are at least short-term benefits for industry and researchers because there are no additional or contradictory state laws that could impede interstate or international collaborations. Patience may be a virtue because Congress or DHHS and FDA may take action to create a harmonized approach. Finally, as noted earlier, state courts so far have tended to support institutions in cases involving conflicts about tissue control and ownership. However, it is also possible that Indiana's reliance on the status quo could have a negative impact on research. Institutions may be hesitant to engage in genetic

141. IND. CoDE § 16-39-5-2 (2008).

142. Id.

143. Id.

144. IND. CODE $\S \S 27-8-26-6$ to $27-8-26-7$ (2008).

145. Id.

146. IND. CODE $\S \S 27-8-26-5$ to 27-8-26-9 (2008).

147. N.M. STAT. ANN. § 24-21-4 (West 2008). 
research and biobanking projects due to fears of litigation related to compliance uncertainty. The public may also be reticent to donate specimens to research if it takes place outside of standardized regulations, effectively hindering the long-term sustainability of this kind of research.

\section{A Comprehensive Approach for Indiana}

In addition to the state models that already exist, there may be additional legal approaches that Indiana could take that both respect and adequately protect patients while promoting research efficiency. What follows is a recommendation for a comprehensive set of statutory provisions that address the unique concerns relating to biobanking and genetic research. ${ }^{148}$ Unlike some current state models, these provisions include: a comprehensive legal framework for biobanking and genetic research that addresses informed consent, the protection of genetic privacy from unauthorized disclosures, a model for liability, a plan for implementation by the State Department of Health, and a mechanism for ongoing evaluation and revision.

\section{a. Tiered or blanket informed consent for all tissue use}

The legislative approach recommended herein recognizes the human subjects framework of consent and privacy, yet takes measures to streamline the consent process without compromising individual privacy protections. This approach strives to embody the idea that research efficiency and respect for individual control are not mutually exclusive.

This approach would require obtaining a modified form of actual consent from all donors, either by means of a tiered consent (which allows the donor to choose permissible research uses of a specimen from among several options) or blanket consent (a one-time consent to any future research uses). It would abolish the use of anonymous samples in research without consent, as well as the use of coded samples with the use of IRB exemptions or HIPAA waivers. Although at first glance this appears to increase hurdles for researchers, it should be an acceptable burden for two reasons. First, researchers recognize that the most promising research can be undertaken only in the context of richly annotated samples, and their use usually requires informed consent. Second, if the goal of changing Indiana's laws is to promote the translation of research into clinical products, then the tissues that are banked must be able to support FDA applications, which in turn require that explicit informed consent be obtained.

In recognizing the unique concerns of biobanking and genetic research, the statute could relax the traditional informed consent requirements and strike a compromise by creating an express authorization that tiered or blanket me-

148. There may well be other approaches that would work, or permutations of this model that would better satisfy the diverse interests in the life sciences. 
thods of consent are permissible if they contain sufficient specificity about the research in the informed consent form. The statute could recognize and permit a singular consent and HIPAA authorization for the collection, storage, and use based on whether the tiered or blanket form is used. Although the Privacy Rule stipulates that a research institution shall provide an individual with a "specific and meaningful" 149 description of the research prior to authorizing use of the individual's PHI, some have argued that this provision does not prohibit or invalidate an individual's authorization to use his or her PHI for future research in general. ${ }^{150}$

Allowing each individual the right to decide whether or not to participate in biobank research respects autonomy and individual dignity if the informed consent form discloses in good faith as much information as is practicable. Future legislation with respect to benefits should note that no personal benefit from contribution is expected to arise, and the institution will not provide the individual with any information relating to the results of any genetic testing or research. With respect to risks to the individual, the consent should include the immediate physical dangers of extracting the specimen, any threats to information confidentiality, and insurability and employability based on genetic information. In addition, disclosures should include the types of genetic research that may be performed, partnerships with private entities, and plans to develop commercial products.

Despite heightened respect for the donor's initial decision to donate or decline participation, the institution would gain immense control once the individual donates the specimen and the institution codes it. This solution could also allow for individual withdrawal of the coded specimen and information, but would expressly deny donors a right to transfer, direct, or manage the specimen once donated. The loss of control once the individual donates the specimen would also mean that this solution would not explicitly recognize any individual property right in genetic information or a genetic specimen. This solution would also prohibit re-identifying the specimens and connecting any genetic information to the individual's identity.

149. 45 C.F.R. $\S 164.508$ (c)(1)(ii) (2008).

150. David Wendler notes that the Privacy Rule currently allows individuals to make a single general authorization of their PHI "to be used in future research to find better ways to treat and cure disease." The DHHS has suggested that the Privacy Rule as written contains two shortcomings: (1) individuals authorizing use of their PHI lack the necessary information to make an informed decision; and (2) the Privacy Rule does not require IRB or privacy board review of research uses and disclosures made with individual authorization. Wendler proposes that one time general consent and authorization may be permissible if an IRB reviews and approves future research that would be consistent with the individual's original authorization. David Wendler, One-Time General Consent for Research on Biological Samples, 166 ARCHIVES OF INTERNAL MED. 1449, 1450 (2006). 


\section{b. Disclosures and re-identification}

Specimens should remain coded and re-identification of the specimens should be prohibited. Indiana law should compensate for the current lack of federal protections against unauthorized disclosures of genetic information to employers and insurance companies. This policy would minimize public fear and concern about potential discrimination that might otherwise hinder willingness to donate. This policy could also prevent conditioning an application for employment or insurance coverage on obtaining a genetic test, on particular results of a genetic test, or any other actual, perceived, or assumed genetic characteristics.

\section{c. Liability}

The legislature should adopt a model of civil liability that recognizes the importance of compliance with relevant consent or privacy provisions, and also serves as a possible deterrent from unauthorized disclosures connecting an individual to genetic information. Criminal liability is not advisable, as it may unnecessarily deter research and development interests and investments.

This solution would recognize that a limited class of individuals has standing to bring a claim, recognizing only the individual, the individual's immediate family members, and the attorney general. Despite the narrow class of individuals with standing, the law would recognize the broad class of potential breaching parties and extend a duty and liability to the researchers, physicians, institutions, and research partners involved in the breach. To prevent hindrances to research, the law would not rely on a strict liability model but rather outline a series of violations based on mental intent. Violations could be based on a tiered level, ranging from negligent violations to willful violations. One remedy may include temporary injunctive relief at the minimum, irrespective of the level of intent. Additional remedies could be awarded based on a showing of a particular level of intent, and the law would accordingly specify a minimum amount of money damages based on the nature of the breaching party's intent.

\section{d. Implementation of legislative changes}

A practical way of implementing these legislative changes and creating uniformity among research institutions would be to charge the Indiana State Department of Health with the responsibility of educating Indiana citizens (including health care providers), assisting in the integration of genomic medicine into clinical care, and providing ongoing assessment of Indiana's genetic research laws. 


\section{(I) Outreach and education}

Increasing the public's genomic literacy should occur in several environments by including a legislative provision requiring the Department of Health to introduce educational components in schools, inform the general public via media outlets, and further educate the professional community. The Department of Health could partner with the Department of Education to integrate information about genetics and health care into the public school health curriculum. The Department of Health's public education effort should target varied media outlets such as public service advertising and informational websites, in addition to brochures and pamphlets disseminated by health care providers. Recently revised umbilical cord blood collection laws in California provide a useful model of how to inform the public of important research endeavors while notifying them of the legal requirements related to donation. The California statute lists various methods to increase public awareness through the use of brochures, television, print media, radio, internet websites, outdoor advertising, and other media. Similar to cord blood banking, the public should be fully informed of the benefits of genetic research which could be accomplished in a comparable manner. ${ }^{151}$ The Department of Health should also devise a system to provide ongoing education and training to health care professionals to increase awareness of available technologies and promote integration of translational medicine into health care delivery.

\section{(II) Integration of genomics into personal health care}

Research using banked materials should yield improvements in translational medicine, such as genetic screening tests and targeted therapies. Indiana law should describe the importance of returning broad public health benefits based on ongoing field advancements by increasing the use of genetic screening, counseling, and targeted therapies to be coordinated by the Department of Health.

Consideration may also be given to how genetic screening tests and personalized medicine will be provided as a viable health care option, which includes financing and reimbursement issues that impact genetic services delivery. This section could specify how public and private insurance will classify the use of genetic screening and testing services and give the Department of Health the task of compiling additional findings relating to data on reimbursement rates, financing, delivery, and any potential changes needed to encourage public utilization of genetic services. 


\section{(III) Evaluation and ongoing advisement}

The Indiana State Legislature and Department of Health should develop a system of review to assess the progress of the goals enumerated by the Department of Health. The Department could appoint a committee to monitor and address possible barriers to implementation of collection initiatives, new research discoveries, and empirical data to show improvements in diagnosis and treatment of patients using the state's genetic services.

The Department of Health should create a mechanism such as an advisory group to remain knowledgeable and compliant with relevant legal changes at the federal level and in case law. Although the recently proposed Genomic and Personalized Medicine Act of $2006^{152}$ has not been enacted, the Congressional pattern of passing similar legislation such as the PREEMIE Act of $2006^{153}$ suggests that Congress may enact federal laws to promote the development of biobanking initiatives. This type of law may provide financial support through federal grants or clarify ambiguities in current regulations and guidance by, for example, delineating substantive requirements for an informed consent form or defining ownership. Similarly, if the Genetic Information Nondiscrimination Act (or similar legislation) passes on the federal level, state legislation and practices should reflect prohibitions against discrimination on the basis of genetic information. Additionally, the advisory group should create a working plan to educate both the public and professional communities on how to comply with these legal changes. This advisory group should also monitor updates in case law across the country because even nonbinding precedent in this subject area has strongly influenced subsequent dispute resolutions.

The Department of Health should also assign a committee to monitor current ethical, legal, and social issues related to biobank research, including unresolved or ambiguous issues related to informed consent, privacy and confidentiality, commercialization, and how to determine the benefits that accrue to the public through better health care and/or local economic development.

152. The Genomic and Personalized Medicine Act proposes standardizing portions of informed consent forms "including those that allow multiple uses of data for research purposes" which suggests a move toward permitting tiered or blanket consent in the biobanking context and/or data sharing arrangements. This bill would also make recommendations to definitively address ownership of the samples and information. Enactment of S. 3822, or a similar law, could standardize legal approaches and render moot portions of the current ethical debate based on legal ambiguities. Genomics and Personalized Medicine Act, S. 3822, 109th Cong. (2006), available at $\mathrm{http} / / \mathrm{www}$.govtrack.us/data/us/bills.text/109/s/s3822.pdf.

153. PREEMIE Act, S. 707 109th Cong. (2006), available at http://www.govtrack.us/data /us/bills.text/109/s/s707.pdf. 


\section{CONCLUSION}

Biobanking's promises of advances in translational research are contingent upon collection of the public's biological specimens, which requires maintaining the trust of both the public and potential investors to support translational research. Previous solutions have erroneously submitted to the proposition that research efficiency and respect for donors are mutually exclusive. This has resulted in some instances of donor dissatisfaction and legal battles, a losing solution for both donors and institutions. A comprehensive legislative solution can work to minimize legal uncertainty related to the collection, use, storage, and disclosure of individuals' sensitive and invaluable genetic samples and information. Educating and engaging both the public and institutions through such a solution will streamline the biobanking process, encouraging altruistic donation while producing beneficial research innovations. 